\title{
Konstruksi Berita Perkosaan Reynhard Sinaga Di Tirto Dan Tribunnews
}

\author{
Sakhnaz Rizki Amelia Aftrinanda*, Fajar Junaedi \\ Universitas Muhammadiyah Yogyakarta, Yogyakarta, Indonesia \\ *e-mail: sakhnaz.rizki.fisip17@ mail.umy.ac.id
}

\begin{abstract}
This research departs from a phenomenon that is in the spotlight in early 2020, namely about rape involving Reynhard Sinaga, an Indonesian citizen who is in the UK. It was reported that the rape was the largest rape case in the UK. Tirto and Tribunnews, two of Indonesia's leading online media outlets that reported on the rape case committed by Reynhard Sinaga in abundant portions with the title of the click bait. This research was conducted by qualitative framing analysis method using a library study approach. The analytical methods used in this research is framing of William A. Gamson and Andre Modigliani. The result of the study shows different framing. Tirto framing show Reynhard Sinaga rape case was not related to his background as homosexual. But, in Tribunnews framing, Reynhard Sinaga criminal case was related to his sexual orientation as homosexual. Tribunnews framing show Reynhard Sinaga rape case background related to his private life. For Tirto, the most important thing is to protect eye witness and victim. Click bait in online digital has been common in Tribunnews, not in Tirto. It means Tribunnews try to get attention from audience by using click bait.
\end{abstract}

Keywords: Framing Analysis, Sexual Abuse, Reynhard Sinaga, Tirto, Tribunnews

\begin{abstract}
ABSTRAK
Penelitian ini dimulai dari kejadian yang menjadi perhatian pada permulaan tahun 2020, yaitu mengenai pemerkosaan yang menyeret nama Reynhard Sinaga, warga negara Indonesia yang berada di Inggris. Diinformasikan bahwa pemerkosaan yang dilakukan tersebut merupakan kasus pemerkosaan terbesar di Inggris. Tirto dan Tribunnews, dua media daring terkemuka di Indonesia yang memberitakan kasus perkosaan yang dilakukan Reynhard Sinaga dalam porsi yang berlimpah dengan judul yang umpan klik. Riset ini menggunakan metode analisis framing kualitatif dengan pendekatan studi kepustakaan. Metode analisis yang digunakan adalah framing dari William A. Gamson dan Andre Modigliani. Temuan riset ini menunjukan adanya perbedaan bingkai antara kedua media. Tirto membingkai kasus yang dilakukan Reynhard Sinaga berkaitan dengan latar belakang seksualnya sebagai homoseksual. Sedangkan Tribunnews justru membingkai kasus ini karena dilatarbelakangi orientasi seksual pelaku. Tribunnews bahkan membingkai kasus perkosaan yang dilakukan Reynhard Sinaga berkaitan dengan kehidupan pribadinya. Sebaliknya Tirto justru mendepankan bingkai bahwa saksi dan korban perlu mendapat perlindungan. Framing Tribunnews ini memperlihatkan fenomena umpan klik untuk meraih kunjungan pembaca yang tinggi, demi mendapatkan iklan.
\end{abstract}

Kata kunci : Analisis Framing, Kekerasan Seksual, Reynhard Sinaga, Tirto, Tribunnews

\section{Pendahuluan}

Media dianggap sebagai institusi yang kuat dalam memengaruhi opini dan pikiran publik terkait isu tertentu. Media juga mengkonstruksi realitas berdasarkan versi mereka sendiri. Kellner mengungkapkan bahwa media membantu bagaimana publik melihat dunia dan mengevaluasi nilai baik 
dan buruk, positif, dan negatif (Hilde \& Kellner, 1996).

Pada hakikatnya media massa mempunyai peran sebagai penghantar dalam menyebarkan beragam pengetahuan, melakukan aktivitas di area publik yang dapat dijangkau anggota masyarakat secara terbuka, leluasa, umum, dan mudah, serta interaksi antara pengirim dan penerima setara dan sama, juga dapat merengkuh lebih banyak orang daripada institusi lainnya (McQuail, 2010).

Seiring dengan perkembangan teknologi, internet membangun peluang penyajian berita yang bersifat daring atau dikenal dengan online. Situs berita daring saat ini didominasi oleh pembaca karena kemudahan, kecepatan akses, dan dekat dengan pembaca, yang merupakan korelasi logis dari kemajuan teknologi komunikasi.

Pada awal bulan Januari 2020, Indonesia menjadi pembicaraan di kancah internasional dengan adanya berita perkosaan di Inggris yang pelakunya merupakan seorang mahasiswa doktoral asal Indonesia, Reynhard Sinaga. Kedua negara ramai memberitakan kasus ini. Pengadilan Inggris mengemukakan bahwa ini merupakan kasus pemerkosaan oleh perseorangan terbesar dalam sejarah dunia berdasarkan banyaknya korban. Kronologi pemerkosaan berlangsung dan tahapan pengadilan dijelaskan dengan detail oleh media Inggris, salah satunya BBC. Reynhard yang terbukti memperkosa hampir E-ISSN: 2580-6955
200 orang dan divonis seumur hidup oleh pengadilan Inggris telah ditangkap sejak 2017. Akan tetapi media Inggris baru mengungkap kasusnya setelah hukuman diputuskan pada penghujung Desember 2019.

Di Indonesia, fenomena orientasi seksual sesama jenis saja sudah dianggap sebagai suatu bentuk penyimpangan, apalagi kasus berupa pemerkosaan terhadap sesama jenis. Meskipun kejadiannya di luar negeri, yakni Inggris, tetapi pelaku pelecehan seksual itu adalah Reynhard Sinaga, seorang Warga Negara Indonesia (WNI) sehingga kasus tersebut menjadi berita yang sangat viral di Indonesia, bahkan menghebohkan dunia karena diduga korbannya berjumlah ratusan. Kasus Reynhard Sinaga ini akhirnya marak diberitakan oleh media massa di Indonesia, mulai dari media cetak, media elektronik, hingga media daring. Menurut pengamatan peneliti lebih dari satu pekan, media daring membahas kasus ini dengan menggunakan diksi yang multitafsir.

Sementara itu di Indonesia, yang seharusnya membuat produk jurnalistik informatif, kritis, dan edukatif dengan ketentuan dari Kode Etik Jurnalistik yang mengharuskan produk jurnalistik seimbang dan faktual, banyak berita malah berbias gender dan victim blaming yang menambah buruk perspektif masyarakat terhadap para penyintas. 
Penelitian Ayu Erivah Rossy dan Umaimah Wahid di media daring Detik.com menunjukkan pada dasarnya berita perkosaan lebih menekankan unsur fakta dan informasi. Hal ini dapat dilihat dari hasil yang didapatkan bahwa penulisan tema kronologis tindak perkosaan yang terjadi mendominasi dalam pemberitaan perkosaan di media ini. Tema kronologis dimaksudkan untuk menjelaskan atau menceritakan dengan detil tindak pemerkosaan, yang menunjukan masalah kesenjangan relasi kuasa antara lakilaki dengan perempuan (Rossy \& Wahid, 2016).

Dengan mengetik keyword Reynhard Sinaga di mesin pencari internet, maka artikel-artikel yang keluar dari media Indonesia sebagian besar bersifat clickbait yang menyelidiki hal-hal di luar konteks kasus perkosaan, dari mulai "selfie ganteng", gawai yang dimiliki, hingga rumah baru orang tuanya.

Perkara ini pun diinterpretasi secara beragam oleh sejumlah media daring Indonesia, diantaranya adalah Tirto dan Tribunnews. Peneliti memilih portal berita Tirto sebagai obyek penelitian dikarenakan untuk kategori media yang masih baru dan muda, Tirto dapat menduduki posisi yang populer di Indonesia. Dalam penghitungan ranking situs internet Alexa menyebutkan bahwa Tirto ada di peringkat ke-52 sebagai website atau situs yang kerap dikunjungi warga Indonesia. Menurut penelitian yang E-ISSN: 2580-6955 dilakukan oleh Muji Rahayu dan Herlina Agustin menunjukkan bahwa Tirto adalah media yang memiliki perhatian tentang isu kekerasan seksual. Penelitian keduanya menunjukan bahwa Tirto menjadikan berita tentang hal ini menjadi relevan untuk disorot karena isu ini menjadi isu yang krusial di Indonesia. Selain itu, Tirto adalah media berbasis analisis media dan data yang menggunakan sumber-sumber dengan kredibilitas tinggi (Rahayu \& Agustin, 2019). Sejurus dengan penelitian di atas, penelitian ini juga mengangkat konstruksi pemberitaan media tentang kekerasan seksual. Bedanya Muji Rahayu dan Herlina Agustin meneliti berita tentang kekerasan seksual heteroseksual yang dialami oleh perempuan, sedangkan penelitian ini adalah kasus perkosaan yang terjadi dalam ranah orientasi homoseksual.

Penelitian yang dilakukan oleh I Gusti Ayu Sri Hartari, Ni Made Ras Amanda Gelgel, dan Ni Luh Ramaswati Purnawan mengungkapkan bahwa Tribunnews.com merupakan media online terpopuler dengan jumlah pengunjung terbanyak. Tribunnews mempunyai kemampuan pemberitaan yang cepat dan segar karena ditunjang oleh 28 Tribun network dan dengan nyaris 500 wartawan dan. Ini memberikan kapasitas bagi Tribunnews dalam menampilkan informasi secara aktual dan menjadi media daring dengan banyak pengunjung. Penelitian mereka menunjukan bahwa dalam berita Publisher : UMSU Press 
kekerasan seksual Tribunnews.com memiliki kecenderungan menggunakan pilihan kata yang berbias pada penulisan berita kekerasan seksual (Hartari et al., 2018)

Semenjak kasus Reynhard Sinaga menjadi perbincangan, Tribunnews menjadi portal berita daring yang banyak memberitakan kasus tersebut. Namun beritaberita yang disajikan menunjukkan indikasi inkonsistensi dan tidak fokus hanya pada kasus. Tribunnews terkesan membela pelaku dengan menyebutkan kebaikan menurut pendapat rekannya, ketampanan, dan betapa pandainya Reynhard selama menempuh pendidikan. Hal ini yang akan coba dikaji lebih lanjut dalam riset ini.

Nikodemus Niko dan Alfin Dwi Rahmawan (2020) meneliti kasus Reynhard Sinaga dalam perpektif sosiologi. Keduanya menyatakan bahwa masyarakat di tanah air kebanyakan masih berpikir bahwa perbuatan kriminal pemerkosaan bersangkutan erat dengan seksualitas. Seksualitas Reynhard sebagai homoseksual lebih banyak dikutuk dan dikecam dibanding perbuatan kriminal yang dilakukannya. (Niko \& Rahmawan, 2020).

Berdasarkan latar belakang di atas, rumusan masalah dalam riset ini adalah bagaimana konstruksi berita perkosaan Reynhard Sinaga di Tirto dan Tribunnews? Tujuan riset ini adalah untuk mengetahui konstruksi berita perkosaan Reynhard Sinaga di Tirto dan Tribunnews.
Untuk menganalisis suatu berita, secara garis besar dapat dilakukan dengan analisis teks (termasuk analisis framing) dan wacana kritis. Penelitian ini akan menggunakan analisis framing yang termasuk ke dalam paradigma konstruktivisme. Proses framing menjadikan media massa sebagai forum dimana informasi tentang masalah tertentu diperebutkan dalam suatu perang simbolik antara berbagai pihak yang sama-sama menginginkan pandangannya didukung oleh para pembaca. Secara garis besar, framing merupakan seleksi dan penekanan aspekaspek realitas melalui beberapa cara seperti penempatan (kontekstual), pengulangan, implikasi terhadap karakter budaya, generalisasi, simplifikasi, dan sebagainya. Tujuannya adalah untuk membuat aspekaspek tertentu dari realitas yang diwacanakan menjadi lebih terlihat, dimengerti, dan impresif untuk publik. Framing juga memilih beberapa aspek realitas yang dirasakan dan membuatnya lebih menonjol dalam teks komunikasi dengan cara mempromosikan definisi masalah tertentu.

Penelitian yang dilakukan Diah Permata Sari menjabarkan pada sudut pandang komunikasi, analisis framing dipakai untuk mengulas sistem atau ideologi media saat mengkonstruksikan fakta. Dengan penetapan juga pengulangan gambar dan kata, maka menguatkan kata-kata dan visual images yang merujuk pada beberapa isu.

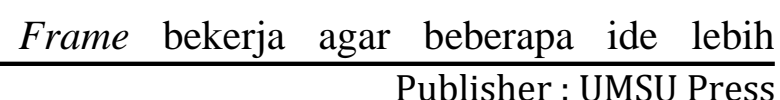


dominan di dalam teks, atau setidaknya yang lain tidak lebih menonjol, sehingga tidak terlihat samasekali. Namun, frame tidak menyingkirkan semua inkonsistensi informasi, sehingga teks tak terelakkan dapat berisi beberapa data yang janggal. Namun dengan penempatan, pengulangan, dan memperkuat implikasi satu sama lain, katakata atau image yang terbentuk menjadikan sebuah interpretasi pokok lebih bisa terlihat, dimengerti dan impresif daripada yang lainnya (Imawan, 2006).

Pamela J. Shoemaker dan Stephen Reese menyebutkan bahwa substansi media pada dasarnya adalah konstruksi sosial, dan dengan demikian tidak pernah dapat menemukan analoginya dalam beberapa tolok ukur eksternal. Isi media dianggap sebagai sebuah "cermin" dari realitas. Distorsi dalam pengertian ini menjadi tidak relevan; realitas sosial memiliki makna tersendiri. Realitas yang dibangun oleh media telah mengambil tempatnya berdampingan dengan konstruksi sosial lainnya, seperti penyakit mental, kriminalitas, seksualitas, jenis kelamin, ras, dan identitas lain yang tidak lagi dianggap "alami". Jika isi media adalah sebuah konstruksi, maka untuk memahami bagaimana media mengemas berita perlu memahami paradigma konstruktivisme (Shoemaker \& Reese, 2013).

Sejumlah definisi telah diajukan untuk menyempurnakan konsep framing. Menurut Robert Entman, sebuah framing ditentukan sebagian besar oleh hasil atau efeknya. Ketika media membingkai, yang terjadi adalah memilah beberapa aspek dari realitas yang dirasakan dan membuatnya lebih dominan dalam komunikasi teks untuk mempromosikan interpretasi suatu masalah, interpretasi kausal, evaluasi moral, dan / atau rekomendasi penyelesaian (Reese, 2008).

Pengaplikasian judul artikel click bait kerap dipakai oleh media - media daring untuk menarik atensi pembaca dengan mengusik rasa ingin tahu yang muncul akibat adanya ketimpangan informasi antara apa yang pembaca ketahui dan apa yang ingin pembaca ketahui. Penggunaan judul dengan strategi naratif dengan memberikan informasi yang tidak utuh atau bahkan ambigu untuk mengusik rasa ingin tahu yang kemudian menggiring pembaca supaya melakukan klik judul artikel untuk membaca lebih lanjut artikel tersebut untuk memenuhi rasa keingintahuannya. Judul artikel click bait sering kali berfokus pada topik selebritis, rumor, bahkan ada yang tidak memiliki nilai berita sama sekali. Tujuan utama dari penggunaan judul artikel click bait adalah supaya statistik kunjungan meningkat yang selanjutnya digunakan untuk memperoleh pendapatan melalui iklan (Hadiyat, 2019).

\section{Metode Penelitian}

Jenis penelitian ini adalah deskriptif kualitatif, dengan paradigma konstruktivistik. 
Teknik pengumpulan data dilakukan dengan pengumpulan dokumentasi.

Teknik analisis menggunakan analisis model framing William A. Gamson dan Andre Modigliani, dengan argumen bahwa model ini yang sesuai untuk menjawab pertanyaan penelitian ini.

Gamson dan Modigliani menyebutkan tentang dua perangkat dalam analisis framing. Pertama, framing device (perangkat framing), yaitu perangkat yang berhubungan dan berhubungan langsung dengan ide dasar atau bingkai yang ditonjolkan dalam teks berita. Perangkat framing ini ditandai dengan pemakaian kata, kalimat, grafik atau gambar dan metafora tertentu (Eriyanto, 2002). Gamson dan Modigliani menyebutkan tentang lima perangkat analisis ini yaitu gambar visual (visual images), metaphora (metaphor), slogan (catchphrases), penggambaran (depiction), dan contoh (exemplar). Lima perangkat ini sering digunakan oleh media untuk mengembangkan bingkai media sebagai bagian dari cerita, dengan pengecualian pada perangkat slogan yang tidak terlalu sering muncul (Zoch, 2008)

Kedua, reasoning device (perangkat penalaran) yaitu sebuah gagasan tidak hanya memuat kata atau kalimat, gagasan itu juga selalu ditandai oleh dasar pembenar tertentu, alasan tertentu dan sebagainya. Dasar pembenaran dan penalaran tersebut bukan hanya menguatkan suatu gagasan atau E-ISSN: 2580-6955 pandangan, melainkan lebih jauh membuat pendapat atau gagasan tampak benar, abash, dan demikian adanya. Lewat aspek penalaran tersebut, khalayak akan menerima pesan itu sehingga tampak sebagai kebenaran, alamiah dan wajar. Sebaliknya, kalau dalam suatu teks tidak terdapat elemen penalaran demikian, gagasan akan tampak aneh, tidak beralasan dan orang dengan mudah mempertanyakan pesan atau gagasan tersebut (Eriyanto, 2002).

\section{Hasil Penelitian dan Pembahasan}

Dalam penelitian ini yang menjadi subjek penelitiannya adalah berita-berita perkosaan oleh Reynhard Sinaga yang dimuat dalam Tirto dan Tribunnews dengan objek penelitiannya adalah kecenderungan kontenkonten pemberitaan kasus perkosaan. Sehubungan dengan tujuan penelitian ini yaitu mengetahui dan menggambarkan kecenderungan konten pemberitaan perkosaan yang dimuat di media online Tirto dan Tribunnews, maka peneliti membuat kategorisasi framing pada berita-berita yang diteliti.

\section{Framing Tirto}

Tirto memberikan perhatian terhadap kasus yang melibatkan Reynhard Sinaga sejak mula kasus ini menjadi pemberitaan di berbagai media massa di Inggris. Tirto banyak menggunakan sumber dari media yang terbit di Inggris seperti Guardian, BBC dan The Telegraph sebagai sumber berita, yang kemudian dilengkapi dengan pencarian 
informasi tentang Reynhard Sinaga kepada oleh Tirto mengenai kasus perkosaan yang orang-orang yang berada di Indonesia. melibatkan Reynhard Sinaga.

Berikut ini adalah berita yang dipublikasikan

Tabel 1: Berita Tirto.id tentang Reynhard Sinaga

\begin{tabular}{|c|c|c|c|c|}
\hline No & Judul Berita & Tautan & $\begin{array}{c}\text { Tanggal } \\
\text { Berita }\end{array}$ & Ket \\
\hline 1 & $\begin{array}{l}\text { Kasus } \quad \text { Reynhard } \\
\text { Pemerkosaan Terburuk di Sejarah }\end{array}$ & https://tirto.id/eq9S & 7 Januari 2020 & Ilustrasi \\
\hline 2 & $\begin{array}{l}\text { Polri akan Cek Catatan Kriminal } \\
\text { Pemerkosa Reynhard Sinaga }\end{array}$ & $\underline{\text { https://tirto.id/erba }}$ & 7 Januari 2020 & Visual Sexual Abuse \\
\hline 3 & $\begin{array}{l}\text { Reynhard Sinaga, Pemerkosa Paling } \\
\text { Jahat di Inggris dari Indonesia }\end{array}$ & https://tirto.id/eq97 & 7 Januari 2020 & \\
\hline 4 & $\begin{array}{l}\text { Reynhard Sinaga, Pemerkosa } 136 \text { Pria di } \\
\text { Inggris Dihukum Seumur Hidup Tahun } \\
2015 \text { Ini }\end{array}$ & $\underline{\text { https://tirto.id/eq9o }}$ & 7 Januari 2020 & $\begin{array}{l}\text { Lukisan tentang } \\
\text { kekerasan seksual }\end{array}$ \\
\hline 5 & $\begin{array}{l}\text { Kasus Reynhard Sinaga: Kekerasan } \\
\text { Seksual Tak Kenal Orientasi Seks }\end{array}$ & $\underline{\text { https://tirto.id/erci }}$ & 8 Januari 2020 & Foto Reynhard \\
\hline 6 & $\begin{array}{l}\text { Skema Kejahatan Reynhard Sinaga dan } \\
\text { Faktor 'Kecerdasan' }\end{array}$ & $\begin{array}{l}\text { https://tirto.id/skem } \\
\text { a-kejahatan- } \\
\text { reynhard-sinaga- } \\
\text { dan-faktor- } \\
\text { kecerdasan-erBt }\end{array}$ & $\begin{array}{ll}15 & \text { Januari } \\
2020 & \end{array}$ & $\begin{array}{l}\text { Infografis kejahatan } \\
\text { seksual Reynhard }\end{array}$ \\
\hline
\end{tabular}

Berdasarkan pemberitaan yang dibuat oleh Tirto, framing berita media daring ini bisa diuraikan sebagai berikut:

\section{a. Kejahatan Reynhard Sinaga Tidak}

\section{Berkaitan dengan Orientasi Seksual}

Tirto membingkai kejahatan seksual yang dilakukan Reynhard Sinaga dalam perangkat framing dan perangkat penalaran sebagai tindak kriminalitas yang tidak berkaitan dengan orientasi seksualitas yang homoseksual. Pada perangkat framing (framing devices), hal ini bisa dianalisis sebagai berikut. Dalam berita berjudul Kasus Reynhard Sinaga: Kekerasan Seksual Tak Kenal Orientasi Seks, secara jelas Tirto memberikan contoh (exemplar) sebagai berikut, kejahatan Reynhard tidak ada hubungannya dengan orientasi seksualnya. Menganggap homoseksual sebagai pelaku E-ISSN: 2580-6955 kekerasan adalah tuduhan yang tidak berdasar. Contoh yang diberikan Tirto ini adalah sebuah kutipan langsung dengan narasumber Ryan Kobarri, ketua Arus Pelangi, sebuah organisasi organisasi yang fokus dalam advokasi LGBT.

Contoh yang lain ditulis Tirto dengan mengutip sebuah tweet di Twitter dari CoDirector Hollaback! Jakarta, Anindya Restuviani dalam kutipan langsung, "Setiap kali saya melihat cuitan di Twitter yang menyerang LGBT saat membahas soal pemerkosa Reynhard membuat saya mau menampar mereka dengan sekitar 407 ribu kasus kekerasan seksual di Indonesia dengan mayoritas pelakunya adalah laki-laki heteroseksual."

Dalam berita yang sama, Tirto menggambarkan (depiction) pembelaan pada 
homoseksualitas dengan menyebutkan bahwa diskriminasi yang berdampak pada generalisasi kelompok homoseksual lain. Metafora yang dilekatkan kepada Reynhard Sinaga oleh Tirto adalah predator seksual berantai jahat. Metafora ini ditulis Tirto berdasarkan kutipan langsung pernyataan Hakim Suzanne Goddard QC yang menyebutkan "Reynhard Sinaga adalah seorang predator seksual berantai jahat, yang memangsa para pria muda,". Metafor ini bisa dijumpai dalam berita berjudul Reynhard Sinaga, Pemerkosa 136 Pria di Inggris Dihukum Seumur Hidup.

Tirto berusaha melepaskan orientasi seksual Reynhard Sinaga. Tirto secara jelas menggambarkan (depiction) bahwa Reynhard Sinaga sebagai pemerkosa paling jahat, sebagaimana bisa ditemui dalam judul berita Pemerkosa Paling Jahat di Inggris dari Indonesia.

Tirto melengkapi perangkat framing tentang kejahatan yang dilakukan oleh Reynhard Sinaga yang tidak seharusnya dikaitkan dengan orientasi seksual dengan lukisan abstrak yang menampilkan seorang perempuan yang dikepung beberapa tangan. Alih-alih menampilkan laki-laki, Tirto justru menampilkan perempuan.

Perangkat penalaran (reasoning device) yang terlihat dalam pemberitaan Tirto adalah menyatakan bahwa kejahatan seksual bisa dilakukan oleh siapapun tanpa memandang orientasi seksualnya. Tirto menyebutkan E-ISSN: 2580-6955 bahwa reaksi masyarakat yang malah menyoroti orientasi seksual Reynhard Sinaga yang terjadi di media massa Indonesia menunjukkan sikap diskriminasi dan menjadi hal yang tak adil.

\section{b. Perlindungan Korban yang Masih}

\section{Kurang di Indonesia}

Kasus kriminalitas yang dilakukan oleh Reynhard Sinaga memang terjadi di Inggris. Meskipun demikian Tirto membingkai kasus ini adalah perspektif perlindungan terhadap korbam yang masih kurang di Indonesia. Tirto membandingkan dengan perlindungan korban di Inggris. Framing Tirto ini bisa dijumpai dalam contoh yang dikutip Tirto dari penelitian Susan McDonald dan Adamira Tijerino. Penelitian keduanya yang berjudul Male Survivors of Sexual Abuse and Assault (2013) menjadi contoh rujukan Tirto. Mereka melakukan wawancara terhadap tujuh korban yang mau diwawancarai, dua orang merasa malu, dan lima lainnya yakin (jika mereka bicara) mereka tak akan dipercaya. Hal itulah yang menyebabkan korban memilih bungkam dan memendam peristiwa itu. Contoh ini bisa dijumpai dalam berita berjudul Skema Kejahatan Reynhard Sinaga dan Faktor 'Kecerdasan'.

Contoh yang menjadi perangkat framing Tirto ini dibandingkan dengan kasus perkosaan yang terjadi di Indonesia. Dalam berita berjudul Kasus Reynhard Sinaga: Kekerasan Seksual Tak Kenal Orientasi Seks, Tirto beberapa contoh gagalnya perlindungan 
korban di Indonesia. Pertama, salah satu kasus pengungkapan kasus prostitusi online yang menyeret nama artis dengan inisial VA di Jawa Timur, justru aparat yang mengungkapkan namanya. Padahal, saat itu status mereka masih menjadi saksi. Kedua, Tak hanya itu,sejumlah korban kekerasan seksual di Indonesia justru menjadi korban ganda akibat hukum yang masih belum berpihak kepada korban. Baiq Nuril merupakan salah satu contohnya. Baiq Nuril selaku korban kekerasan seksual justru dituntut oleh pelakunya menggunakan Undang-undang Informasi dan Transaksi Elektronik. Ketiga, korban pemerkosaan di Jambi, WA (15), justru dijerat pasal aborsi akibat dari pengguguran yang dilakukan dia selepas pemerkosaan oleh kakak kandungnya.

Tirto menggambarkan kejahatan yang dilakukan Reynhard Sinaga sebagai "the most prolific rapist" dalam berita berjudul Polri akan Cek Catatan Kriminal Pemerkosa Reynhard Sinaga. Dalam berita berjudul Kasus Reynhard Sinaga Jadi Pemerkosaan Terburuk di Sejarah Inggris, Tirto menggambarkan Reynhard Sinaga pemerkosa paling produktif dalam sejarah hukum Inggris".

Sosok Reynhard Sinaga, menurut Tirto, digambarkan oleh para korbannya sebagai pria kecil yang tersenyum dalam kacamata berbingkai hitam, yang tampak tidak berbahaya. Penggambaran ini bisa ditemui E-ISSN: 2580-6955 dalam berita berjudul Reynhard Sinaga, Pemerkosa Paling Jahat di Inggris dari Indonesia.

Dalam berita di atas, Tirto mengutip pernyataan pengacara Reynhard Sinaga yang menyebutkan metafor bahwa apa yang dilakukan oleh "fantasi bermain peran." Masih dalam berita ini, Tirto mengutip pernyataan hakim yang memvonis Reynhard Sinaga yang menyebutkan demikian, "Anda adalah individu berbahaya... yang tidak akan pernah aman untuk dilepaskan.”.

Tirto melengkapi perangkat framing tentang perlunya perlindungan korban dengan infografis tentang kejahatan yang dilakukan oleh Reynhard Sinaga.

Sedangkan dalam perangkat penalarannya, Tirto menyebutkan bahwa apa yang dilakukan oleh pemerintah, aparat keamanan dan media di Inggris menjadi bentuk perlindungan terhadap korban. Media di Inggris dan aparat keamanan sangat berhati-hati dalam menyebutkan identitas korban, bahkan inisial korban pun diberitakan. Hal ini berbeda dengan media massa di Indonesia yang cenderung menampilkan identitas korban secara terangterangan.

\section{Framing Tribunnews}

Berita yang disampaikan Tribunnews terhadap kasus yang melibatkan Reynhard Sinaga banyak menggunakan sumber dari media Indonesia seperti BBC News Indonesia 
dan wawancara pencarian informasi dengan dipublikasikan oleh Tribunnews mengenai orang-orang di sekitar Reynhard sebagai kasus perkosaan yang melibatkan Reynhard sumber berita. Berikut ini adalah berita yang Sinaga.

Tabel 2: Berita tribunnews.com tentang Reynhard Sinaga

\begin{tabular}{|c|c|c|c|c|}
\hline No & Judul Berita & Tautan & $\begin{array}{c}\text { Tanggal } \\
\text { Berita }\end{array}$ & Ket \\
\hline 1 & $\begin{array}{l}\text { Divonis Seumur Hidup, Intip Kemewahan } \\
\text { Reynhard Sinaga, Predator Seksual Puluhan } \\
\text { Pria Inggris }\end{array}$ & tribunnews.com/reynhard/1 & $\begin{array}{l}8 \text { Januari } \\
2020\end{array}$ & $\begin{array}{l}\text { Swafoto } \\
\text { Reynhard }\end{array}$ \\
\hline 2 & $\begin{array}{l}\text { Reynhard Sinaga, Dikenal Pintar Saat } \\
\text { Kuliah di UI dan Mudah Bergaul, Lahir dari } \\
\text { Keluarga Mapan }\end{array}$ & tribunnews.com/reynhard/2 & $\begin{array}{l}7 \text { Januari } \\
2020\end{array}$ & $\begin{array}{l}\text { Swafoto } \\
\text { Reynhard }\end{array}$ \\
\hline 3 & $\begin{array}{l}\text { Foto-Foto Rumah Reynhard Sinaga di } \\
\text { Depok, Rumah Pemerkosa Berantai } \\
\text { Gemparkan Inggris, Viral }\end{array}$ & tribunnews.com/reynhard/3 & $\begin{array}{l}8 \quad \text { Januari } \\
2020\end{array}$ & $\begin{array}{l}\text { Foto rumah } \\
\text { Reynhard }\end{array}$ \\
\hline 4 & $\begin{array}{l}\text { Sejak Kapan Reynhard Sinaga Terjerumus } \\
\text { Penyuka Sesama Jenis? Semua Berawal dari } \\
\text { Kisah Tahun } 2015 \text { Ini }\end{array}$ & tribunnews.com/reynhard/4 & $\begin{array}{l}8 \text { Januari } \\
2020\end{array}$ & \\
\hline 5 & $\begin{array}{l}\text { Reynhard Sinaga, Dikenal Pintar Saat } \\
\text { Kuliah di UI dan Mudah Bergaul, Lahir dari } \\
\text { Keluarga Mapan }\end{array}$ & tribunnews.com/reynhard/5 & $\begin{array}{l}7 \text { Januari } \\
2020\end{array}$ & Foto Reynhard \\
\hline 6 & $\begin{array}{l}\text { Reynhard Sinaga Sempat Mengaku Bekerja } \\
\text { di Man United, Manajemen Sanggah Rumor } \\
\text { Tersebut }\end{array}$ & tribunnews.com/reynhard/6 & $\begin{array}{l}9 \text { Januari } \\
2020\end{array}$ & $\begin{array}{l}\text { Swafoto } \\
\text { Reynhard }\end{array}$ \\
\hline
\end{tabular}

Berdasarkan pemberitaan yang dibuat oleh Tribunnews, framing berita media daring ini bisa diuraikan sebagai berikut:

\section{a. Mengungkap Orientasi Seksual Reynhard adalah Pangkal Persoalan}

Tribunnews membingkai kejahatan seksual yang dilakukan Reynhard Sinaga dalam perangkat framing dan perangkat penalaran sebagai tindak kriminalitas yang berkaitan dengan orientasi seksualitas yaitu homoseksual. Pada perangkat framing (framing devices), hal ini bisa dianalisis sebagai berikut. Dalam berita yang berjudul Sejak Kapan Reynhard Sinaga Terjerumus Penyuka Sesama Jenis? Semua Berawal dari Kisah Tahun 2015 Ini, secara jelas Tribunnews memberikan contoh (exemplar) sebagai berikut, Pada awal tahun 2015, E-ISSN: 2580-6955
Reynhard memberi tahu seorang teman tentang 'pengalamannya' dengan seorang pemuda. Contoh yang dijelaskan Tribunnews ini adalah rincian pesan teks Reynhard kepada teman-temannya melalui aplikasi whatsapp yang dirangkum dari portal berita Inggris yaitu Manchester Evening News. Contoh yang lain ditulis Tribunnews adalah Reynhard Sinaga mengirim pesan itu kepada teman-temannya hanya beberapa jam setelah membius dan memperkosa seorang pria.

Dalam berita yang sama, Tribunnews menggambarkan (depiction) terhadap homoseksualitas yang menjadi akar kejahatan dengan menyebutkannya sebagai berikut, Reynhard Sinagaterjerumus ke dunia penyuka sesama jenis hingga klimaksnya jadi predator seksual. Penggambaran fakta yang Publisher : UMSU Press 
diberikan Tribunnews menggunakan pemilihan kata terjerumus yang memiliki konotasi negatif. Kata 'terjerumus' memiliki arti dalam kelas verba atau kata kerja dapat menyatakan suatu tindakan atau pengalaman yang berarti jatuh dalam kesengsaraan.

Metafora yang ditulis Tribunnews yang disebutkan yaitu seperti menyiratkan Reynhard telah meyakinkan pria straight 'lain' untuk bergabung dengannya di tempat tidur. Metafor ini bisa dijumpai dalam berita berjudul Sejak Kapan Reynhard Sinaga Terjerumus Penyuka Sesama Jenis? Semua Berawal dari Kisah Tahun 2015 Ini.

Tribunnews berusaha mengaitkan orientasi seksual Reynhard Sinaga sebagai akar penyebab perbuatan kriminal yang dilakukannya. Tribunnews secara jelas menggambarkan (depiction) bahwa homoseksual menjadikannya predator seksual.

Tribunnews melengkapi perangkat framing tentang kejahatan yang dilakukan oleh Reynhard Sinaga dikaitkan dengan orientasi seksual dengan mengungkap pesan teks Reynhard kepada teman-temannya mengenai penggunaan obat bius pada pria yang ditemuinya.

Perangkat penalaran (reasoning device) yang terlihat dalam pemberitaan Tribunnews adalah menyatakan orientasi seksual dapat menjadi penyebab seseorang melakukan kekerasan seksual terhadap orang lain, ditambah reaksi masyarakat yang tertarik menyorot orientasi seksual Reynhard Sinaga.

\section{b. Mengungkap Ranah Pribadi Reynhard}

\section{Sinaga}

Tribunnews membingkai tragedi kasus kriminalitas yang dilakukan oleh Reynhard Sinaga ini sebagai sesuatu yang entertaining atau menghibur masyarakat. Tribunnews banyak mengungkap hal-hal pribadi yang lebih pantas disebut gosip dibandingkan dengan berita. Framing Tribunnews ini bisa dijumpai dalam berita-beritanya. Mereka melakukan wawancara terhadap orang-orang terdekat Reynhard. Wawancara ini dapat ditemui pada beberapa berita yang diangkat Tribunnews.

Contoh yang menjadi perangkat framing Tribunnews dalam berita berjudul Divonis Seumur Hidup, Intip Kemewahan Reynhard Sinaga, Predator Seksual Puluhan Pria Inggris. Alih-alih mengungkap kasus kriminalitas Reynhard, Tribunnews justru mengangkat kehidupannya yang mewah. Berita lain yang mengungkap hal ini berjudul Foto-Foto Rumah Reynhard Sinaga di Depok, Rumah Pemerkosa Berantai Gemparkan Inggris, Viral. Dalam beritanya, Tribunnews membahas gaya hidup Reynhard yang mewah yang dibuktikan dengan banyak ia mengunjungi klub-klub malam, berpindah ke berbagai apartemen di Manchester, dan bergonta-ganti pasangan.

Kehidupan pribadi Reynhard Sinaga dikaitkan dengan menggambarkannya dalam 
depiction predator seksual. Selain itu Tribunnews juga membuat metafora bahwa kejahatan yang dilakukan oleh Reynhard Sinaga sebagai pemerkosa berantai. Metafora ini menunjukan bahwa kejahatan yang dilakukan oleh Reynhard Sinaga terjadi secara berurutan.

Tidak hanya mengungkap kemewahannya, Tribunnews juga mulai mengulik dan mengungkap tempat kerja Reynhard Sinaga sebagai exemplar untuk memperkuat framing tentang latar belakang pribadinya. Exemplar yang dibuat oleh Tribunnews adalah bahwa Reynhard Sinaga sempat mengaku pernah bekerja di salah satu klub sepak bola yaitu Manchester United, meskipun pada akhirnya rumor itu ditolak oleh manajemen terkait.

Selanjutnya exemplar lain adalah bahwa sosok Reynhard Sinaga, menurut Tribunnews yang digambarkan oleh temantemannya sebagai pria ramah, pintar, tidak memilih-milih teman, dan rajin beribadah yang tampak tidak berbahaya. Penggambaran ini bisa ditemui dalam berita berjudul Reynhard Sinaga, Dikenal Pintar Saat Kuliah di UI dan Mudah Bergaul, Lahir dari Keluarga Mapan.

Tribunnews melengkapi perangkat framing tentang kemewahan Reynhard Sinaga dengan visual image berupa foto-foto rumah keluarganya dan foto kelulusan Reynhard Sinaga. Foto ini ditampilkan untuk menunjukan Reynhard Sinaga berasal dari E-ISSN: 2580-6955 keluarga kaya dan sekaligus sosok yang pintar.

Sedangkan dalam perangkat penalarannya, Tribunnews cenderung menampilkan karakter pribadi Reynhard saat bersama teman-temannya dan keluarganya. Perangkat penalaran ini ditampilkan untuk menunjukan bahwa faktor latar belakang kehidupan pribadi keluarga memiliki kaitan dengan kejahatan yang dilakukan oleh Reynhard Sinaga.

\section{Faktor-faktor Framing: Jurnalisme Online Mengejar Traffic}

Pemberitaan tentang kasus kejahatan Reynhard Sinaga dibingkai dalam perangkat pembingkaian dan perangkat penalaran yang berbeda oleh Tirto dan Tribunnews. Tirto membingkai kasus ini dengan tidak mengaitkan kejahatan yang dilakukan Reynhard Sinaga dengan orientasi seksualnya. Sebaliknya, Tribunnews justru membingkai kejahatan Reynhard Sinaga dalam relasinya dengan orientasi seksualnya.

Tribunnews bahkan membingkai relasi ini dalam judul yang click bait seperti ini Sejak Kapan Reynhard Sinaga Terjerumus Penyuka Sesama Jenis? Semua Berawal dari Kisah Tahun 2015 Ini. Judul yang seperti ini menunjukan fenomena yang dinyatakan oleh Pamela J. Shoemaker dan Stephen D. Reese bahwa teknologi internet memungkinkan organisasi media dan pengiklan untuk secara tidak mencolok menangkap informasi tentang 
penggunaan berita, konten hiburan, dan iklan oleh pemirsa. Waktu yang dihabiskan, jumlah klik, dan tampilan halaman memungkinkan organisasi untuk secara langsung mengukur beberapa dimensi minat audiens pada konten dan iklan. Lebih penting lagi, sebuah organisasi berita sebagai hasil dari informasi ini dapat menyesuaikan kontennya untuk penggunanya, atau pelanggannya (Shoemaker \& Reese, 2014).

Faktor dari ekstramedia terutama dari pemasang iklan dan audiens inilah yang menjadi faktor jurnalisme online yang dikemas untuk mendapatkan impresi tinggi dari pembaca media berplatform internet. Pada masa media pra internet, respon dari pembaca terhadap isi pemberitaan tidak bisa terjadi secara langsung (Shoemaker \& Reese, 2014). Di era internet, pembaca bisa menanggapi isi berita secara langsung dan bahkan menyebarkannya melalui media sosial.

Tirto dan Tribunnews menanggapi hal ini secara berbeda. Jika Tribunnews dalam perangkat penalaran dan pembingkaiannya mengaitkan kejahatan Reynhard Sinaga dengan latar belakang seksual dan kehidupan pribadinya untuk meraih impresi yang tinggi, maka Tirto lebih memilih berhati-hati dengan tidak mengaitkan kejahatan Reynhard Sinaga dengan latar belakang orientasi seksualnya. Tirto juga lebih menekankan pada perlunya perlindungan terhadap korban yang masih kurang diperhatikan di Indonesia.
Pemberitaan Tribunnews menunjukan adanya fenomena jurnalisme online yang mengejar jumlah pengunjung pembaca di situs berita. Semakin banyak pembaca yang berkunjung maka semakin tinggi pula jumlah pengiklan yang bisa didapatkan.

\section{Penutup}

Tirto dan Tribunnews membingkai kejahatan yang dilakukan oleh Reynhard Sinaga dalam pembingkaian yang berbeda. Tirto membingkai kasus perkosaan yang dilakukan Reynhard Sinaga tidak berkaitan dengan orientasi seksualnya sebagai homseksual. Tirto juga membingkai tentang perlunya perlindungan hukum terhadap saksi dan korban dalam kasus perkosaan.

Sebaliknya, Tribunnews mengemas bingkai tentang kejahatan Reynhard Sinaga sebagai kasus kriminal yang berkaitan dengan orientasi seksualnya sebagai homoseksual. Tribunnews juga membingkai kejahatan seksual Reynhard Sinaga sebagai kejahatan yang terkait dengan kehidupan pibadinya. Tribunnews banyak menggunakan sumber dari orang-orang yang berhubungan dengan latar belakang Reynhard, seperti teman, orang tua, bahkan asisten rumah tangga untuk memaparkan kepribadian dan kesehariannya. Berita yang ditampilkan memperjelas bingkai bahwa pelaku memiliki kepribadian yang baik di mata orang terdekatnya dan tidak tampak berbahaya samasekali. 
Dapat disimpulkan juga Tribunnews masih mencari celah hiburan dalam sebuah peristiwa dengan mengulik kehidupan pribadi tersangka kekerasan seksual dibandingkan berkonsentrasi pada perbuatan kriminalnya untuk menarik minat pembaca. Adanya fenomena click bait untuk mengejar traffic kunjungan membuat hal ini terjadi. Faktor dari ekstramedia terutama dari pemasang iklan dan audiens inilah yang menjadi faktor jurnalisme online yang dikemas untuk mendapatkan impresi tinggi dari pembaca media berplatform internet.

\section{Daftar Pustaka}

Abdullah, S. N. A. (2019). Analisis Wacana Sara Mills Tentang Kekerasan Perempuan dalam Rumah Tangga Studi Terhadap Pemberitaan Media Kumparan. Jurnal Dakwah Dan Komunikasi, 4(2), 101. https://doi.org/10.29240/jdk.v4i2.1236

Bagus, R. (2020). Kontruksi Kontruksi Sarkasme Media Massa Online Di Indonesia: Judul Pemberitaan Kasus Pelecehan Seksual Reynhard Sinaga. LITERASI: Jurnal Ilmiah Pendidikan Bahasa, Sastra Indonesia Dan Daerah, 10(Volume 10), 85-103. https://doi.org/10.23969/literasi.v10i2. 2227

Eriyanto. (2002). Analisis Framing: Konstruksi, Ideologi dan Politik Media. Yogyakarta: LKIS.

Galvin, K. M., Braithwaite, D. O., Schrodt, P., Bylund, C. L., Galvin, K. M., Braithwaite, D. O., Schrodt, P., \& Bylund, C. L. (2018). Family Communication Theories. In Family Communication. https://doi.org/10.4324/978131522884 6-3

Gunter, B. (1984). Mass Communication Theory: An Introduction. In Social Science Information Studies (Vol. 4, Issue 4). https://doi.org/10.1016/01436236(84)90039-5

Hadiyat, Y. D. (2019). Clickbait on Indonesia Online Media. Journal Pekommas, 4(1), 1-10 . https://doi.org/10.30818/jpkm.2019.20 40101

Hanitzsch, T. (2001). Teori Sistem Sosial dan Paradigma Konstruktivisme: Tantangan Keilmuan Jurnalistik di Era Informasi Thomas. Jornal Da Sociedade Das Ciencias Medicas de Lisboa, 13(Education), 218-229. https://ejournal.unisba.ac.id/index.php/ mediator/issue/view/52/showToc

Hartari, I. G., Gelgel, N. M., \& Purnawan, N. L. (2018). Analisis Isi Berita Kekerasan Seksual Tribunnews.Com (Periode Berita Desember 2018). 112.

Hutami, M. F., \& Sjafirah, N. A. (2019). Framing Media Online Tribunnews.Com Terhadap Sosok Perempuan Dalam Berita Video Pornografi Depok. Jurnal Kajian Jurnalisme, 2(1), 25-43. https://doi.org/10.24198/kj.v2i1.21072

Idrus, N. I., \& Fatima, J. M. (2013). Dalam Siaran Radio SPFM Serta Dampaknya Harassment And Violence Against Women In Makassar City. 2(1), 73-80.

Imawan, T. (2006). Politik Infotainment : Siasat Melayakkan Gosip. Jurnal Komunikologi, 3(2), 53-61.

Karman, K. (2013). Media dan Konstruksi Realitas. Jurnal Studi Komunikasi Dan Media, 16(1), 27. 
https://doi.org/10.31445/jskm.2012.16 0102

Kritzinger, A., \& Steenkamp, L. (2006). Communication development of a young child with foetal retinoid syndrome: a seven-year follow-up study. In The South African journal of communication disorders. Die SuidAfrikaanse tydskrif vir Kommunikasieafwykings (Vol. 53). https://doi.org/10.4102/sajcd.v53i1.198

McQuail, D. (2010). McQuail's Mass Communication Theory 6th Edition. Los Angeles: SAGE.

Muslich, M. (2008). Kekuasaan Media Massa Mengonstruksi Realitas. Jurnal Budaya Dan Seni, 2(36), 150-158. http://sastra.um.ac.id/wpcontent/uploads/2009/10/KekuasaanMedia-Massa-Mengontruksi-RealitasMasnur-Muslich.pdf

Muzakkir, M. (2018). Analisis Framing Dalam Pemberitaan Media. Jurnal Ilmu Komunikasi, 3(2), 183-196. https://doi.org/10.35308/source.v3i2.6 49

Niko, N., \& Rahmawan, A. D. (2020). Supremasi Patriarki: Reaksi Masyarakat Indonesia Dalam Menyikapi Narasi Seksualitas Dan Perkosaan Kasus Reynhard Sinaga. Jurnal Analisa Sosiologi.

Prasetyo, D. E. (20016). Analisis Berita Yuyun dan Para Korban Kejahatan Akibat Minuman Keras di Republika Online edisi 7 Mei 2016. Dunia Komunikasi, 4(3), 127-141. https://ejournal.ilkom.fisipunmul.ac.id/site/?p=2565

Rahayu, M., \& Agustin, H. (2019). Representasi Kekerasan Seksual Terhadap Perempuan Di Situs Berita Tirto.Id. Jurnal Kajian Jurnalisme,
2(1), 115-134.

10.24198/kj.v2i1.21321

Reaksi, S. P. (2020). Masyarakat Indonesia Dalam Reynhard Sinaga. 137-152.

Reese, S. D. (2001). Prologue-Framing public life: A bridging model for media research. Framing Public Life: Perspectives on Media and Our Understanding of the Social World, January 2001, 7-31.

Reese, S. D. (2008). Prologue-Framing Public Life: A Bridging Model for Media Research. In S. D. Reese, O. Gandy, \& A. Grant, Framing Public Life : Perspectives on Media and Our Understanding of the Social World ( $\mathrm{p}$. 10). New Jersey: Lawrence Erlbaum Associates, Inc., Publishers.

Rohmah, R. A. (2017). Potret Wanita Berita Kriminal Pemerkosaan Di Media Online Sindonews.com. Jurnal Pendidikan Rokania, II(2), 247-264.

Rossy, A. E., \& Wahid, U. (2016). Analisi Isi Kekerasan Seksual Dalam Pemberitaan Media Online Detik.Com. Jurnal Komunikasi, 7(2), 152-164. https://doi.org/10.24912/JK.V7I2.15

Sari, D. P. (2018). Analisis Framing Pemberitaan Tiga Tahun Pemerintahan Joko Widodo dan Jusuf Kalla di Majalah Gatra. Jurnal Interaksi 2(2), 145-156.

Schement, J. R. (2001). Encyclopedia of Communication and Information 3 Volumes. New York, Routledge

Shoemaker, P. J., \& Reese, S. D. (2013). Mediating the message in the 21st century: A media sociology perspective. In Mediating the Message in the 21st Century: A Media Sociology Perspective. 
https://doi.org/10.4324/978020393043 4

Shoemaker, P. J., \& Reese, S. (2014).

Mediating the Message in the 21st Century A Media Sociology

Perspective. New York: Routledge.

Susilo, D. (2015). Konstruksi Maskulinitas

Dalam Teks Media : Analisis Wacana

Maskulinitas Dalam Berita

Pemerkosaan Di Situs Berita Online.

International Conference on

Language, Culture and Society, 1-8.
Vreese, C. H. De. (2005). News Framing: Theory and Typology. Information Design Journal, 13(1), 51-62. https://doi.org/10.1075/idjdd.13.1.06vr e

Zoch, L. M. (n.d.). What's Really Important Here?: Media Self-Coverage in the Susan Smith Murder Trial. In Framing Public Life: Perspectives on Media and Our Understanding of the Social World. New Jersey: Lawrence Erlbaum Associates, Inc., Publishers. 